Piotr Chybalski

\title{
Dopuszczalność wycofania wniosku o udzielenie Radzie Ministrów wotum nieufności ${ }^{1}$
}

\begin{abstract}
The admissibility of withdrawal of the motion to pass a vote of no confidence in the Council of Ministers: The author assesses the possibility of withdrawing motion to pass a vote of no confidence in the Council of Ministers, finding it. unacceptable, notwithstanding that this matter has not been literally regulated in law. Although this problem was not analyzed in the constitutional literature, an analysis of the current provisions of the Standing Orders of the supports the above conclusion.
\end{abstract}

Keywords: Council of Ministers, vote of no confidence, Constitution, Standing Orders of the Sejm

Słowa kluczowe: Rada Ministrów, wotum nieufności, Konstytucja, regulamin Sejmu

\section{Przedmiot opinii}

Przedmiotem niniejszej opinii jest prawna ocena dopuszczalności wycofania wniosku o udzielenie Radzie Ministrów wotum nieufności przed rozstrzygnięciem tego wniosku przez Sejm.

\section{Uwagi wstępne}

Zgodnie z art. 158 ust. 1 zdanie pierwsze Konstytucji Sejm wyraża Radzie Ministrów wotum nieufności większością ustawowej liczby posłów na wniosek zgłoszony przez co najmniej 46 posłów i wskazujący imiennie kandydata na Prezesa

1 Opinia prawna w sprawie dopuszczalności wycofania wniosku o udzielenie Radzie Ministrów wotum nieufności sporządzona 17 grudnia 2018 r. na zlecenie zastępcy Szefa Kancelarii Sejmu; BAS-WAKiU 2970/18. 
Rady Ministrów. W regulaminie Sejmu przepisy uzupełniające tę regulację konstytucyjną zawarto w dziale II rozdziale 7 zatytułowanym „Uchwalanie wotum zaufania i wotum nieufności; wybór Rady Ministrów” (art. 112-117). Nie wdając się w szczegółową prezentację tych przepisów, należy podkreślić, że w art. 115 ust. 1 regulaminu Sejmu doprecyzowano, że wniosek ów składa się w formie pisemnej na ręce Marszałka Sejmu. Z kolei art. 115 ust. 2 regulaminu Sejmu, kluczowy dla analizowanego problemu, stanowi, iż po złożeniu wniosku podpisy posłów popierających wniosek nie mogą być wycofane, a także nie mogą być pod nim składane dalsze podpisy.

Mimo że w piśmiennictwie konstytucyjnym nie analizowano, jak dotąd, problemu dopuszczalności wycofania wniosku o udzielenie Radzie Ministrów wotum nieufności, ustalenia doktrynalne rzutują, w moim przekonaniu, na kierunek rozstrzygnięcia tego problemu. Punktem wyjścia dla dalszych rozważań powinno być podkreślenie, że, jakkolwiek wyrażenie przez Sejm wotum nieufności stanowi uchwałę, to: [p] rocedura zgłaszania wniosku o wyrażenie wotum nieufności stanowi procedurę odrębna od procedury, w jakiej Sejm rozpatruje projekty innych uchwał . Nieistotne jest przy tym, że autor odnosi się do trybu udzielenia wotum nieufności ministrowi, a nie Radzie Ministrów. Oba postępowania toczą się bowiem w podobnym trybie, o czym świadczy zawarte w art. 116 ust. 2 regulaminu Sejmu, odnoszącym się do postępowania w sprawie udzielenia wotum nieufności ministrowi, odesłanie do art. 115 regulaminu Sejmu, poświęconego procedurze o udzielenie Radzie Ministrów wotum nieufności.

Należy odnotować, że zdaniem powołanego autora regulaminowe ustalenia analizowanej procedury mają charakter kompletny ${ }^{3}$. Oznaczałoby to, że nie ma podstaw do stosowania, nawet w zakresie nieuwzględnionym w art. 112-117 regulaminu Sejmu, ogólnych przepisów odnoszących się do postępowania ustawodawczego. W takiej sytuacji nie należałoby brać pod uwagę ewentualnego odpowiedniego zastosowania art. 36 ust. 2 regulaminu Sejmu (Wnioskodawca do czasu zakończenia drugiego czytania może wycofać wniesiony przez siebie projekt) ani też art. 36 ust. 3 regulaminu Sejmu (Projekt poselski uważa się również za wycofany, jeżeli do czasu zakończenia drugiego czytania, na skutek cofnięcia poparcia, projekt popiera mniej niż 15 posłów spośród tych, którzy podpisali projekt przed jego wniesieniem). Rezygnując z oceny zasadności poglądu wskazującego na kompletność regulaminowej procedury w sprawie wyrażenia przez Sejm wotum nieufności, należy tylko stwierdzić, że wykluczenie zastosowania w tym postępowaniu przywołanych art. 36 ust. 2 i 3 regulaminu Sejmu wydaje się oczywiste. Po-

2 W. Odrowąż-Sypniewski, Rola przedstawiciela wnioskodawców $w$ procedurze rozpatrywania przez Sejm wniosku o wotum nieufności dla ministra [w:] Regulamin Sejmu w opiniach Biura Analiz Sejmowych, red. W. Odrowąż-Sypniewski, t. I, Warszawa 2010, s. 550 .

3 Ibidem. 
stępowanie w sprawie wyrażenia wotum nieufności nie toczy się według modelu kolejnych czytań, co oznacza, że gdyby uznać ich stosowanie za dopuszczalne w tym postępowaniu, to nie byłoby sposobu, by wskazać, do którego momentu dopuszczalne jest wycofanie wniosku o udzielenie wotum nieufności.

Powyższe uwagi prowadzą do wniosku, że ewentualnych podstaw dla wycofania wniosku o udzielenie Radzie Ministrów wotum nieufności należałoby poszukiwać wyłącznie w regulacjach konstytucyjnych (powołany wyżej art. 158 Konstytucji) bądź regulaminowych. Przepisy te nie odnoszą się expressis verbis do kwestii wycofania wniosku.

\section{Ocena dopuszczalności wycofania wniosku o udzielenie Radzie Ministrów wotum nieufności}

W moim przekonaniu jedynym przepisem, który należałoby brać pod uwagę, analizując przedmiotowy problem, jest wspomniany wcześniej art. 115 ust. 2 regulaminu Sejmu, ustanawiający zakaz wycofywania i dodawania podpisów pod złożonym wnioskiem o udzielenie Radzie Ministrów wotum nieufności. Zdaniem W. Sokolewicza zakaz wycofywania podpisów: ma - jak wolno przypuszczać - przede wszystkim chronić posłów przed ewentualnymi naciskami skłaniajacymi ich do takiej decyzji ${ }^{4}$. Z kolei w opinii K. Wojtyczka rozwiązanie to: ma na celu zapewnienie jasności sytuacji i uniknięcie niepewności co do losów wniosków wskutek wycofywania jednych podpisów i zbierania $w$ to miejsce nowych podpisów.

W doktrynie pojawiła się ostatnio rozbieżność wokół tego, czy w świetle omawianego regulaminowego zakazu wycofywania podpisów zasadne jest stwierdzenie zakończenia postępowania (bez rozstrzygnięcia wniosku) wskutek spadku liczebności grupy posłów popierających wniosek o udzielenie Radzie Ministrów wotum nieufności poniżej wymaganej konstytucyjnie liczby 46, który to spadek nastąpi wskutek wygaśnięcia ( $\mathrm{z}$ dowolnego, przewidzianego przepisami prawa, powodu) mandatów części tych posłów przed rozpatrzeniem wniosku przez Sejm. Przekonanie o zakończeniu (de facto „upadku”) postępowania wyraża większość przedstawicieli doktryny, w szczególności przywołany wyżej W. Sokolewicz ${ }^{6}$, a tak-

4 W. Sokolewicz, Uwagi do art. 158 [w:] Konstytucja Rzeczypospolitej Polskiej. Komentarz, t. I, red. L. Garlicki, Warszawa 1999, s. 32. Zob. też R. Mojak, Parlament a rząd w ustroju Trzeciej Rzeczypospolitej Polskiej, Lublin 2007, s. 563.

5 K. Wojtyczek, Uwagi do art. 115 regulaminu Sejmu [w:] Komentarz do regulaminu Sejmu, red. A. Szmyt, Warszawa 2018, s. 518.

6 W. Sokolewicz, Uwagi do art. 158, op. cit., s. 32, 33. 
że L. Garlicki ${ }^{7}$, S. Patyra ${ }^{8}$ oraz A. Szmyt ${ }^{9}$. Przeciwne stanowisko zajął natomiast niedawno K. Wojtyczek ${ }^{10}$. Jakkolwiek przesądzenie tej kwestii nie jest istotne dla niniejszych rozważań, to warto odnotować, że przy okazji formułowania poglądu odnośnie do konsekwencji prawnych wygaśnięcia mandatów części posłów, którzy poparli wniosek, A. Szmyt stwierdził, że zakończenie postępowania z tej przyczyny stanowi: przykład odstępstwa od założenia, iż złożenie wniosku w sposób nieodwracalny uruchamia dalsza procedure $w$ sensie poddania wniosku petnemu tokowi postępowania ${ }^{11}$. Stanowisko to, w moim przekonaniu trafne, nakazuje postrzegać zakończenie postępowania z przyczyny, o której wspomnieli powołani wyżej autorzy, jako wyjątek. Tym samym, co do zasady, zwykłym sposobem zakończenia postępowania w sprawie udzielenia Radzie Ministrów wotum nieufności powinno być rozstrzygnięcie wniosku w tej sprawie przez Sejm.

Zarysowany stan rzeczy prowadzi do wniosku, że nie jest dopuszczalne wycofanie wniosku o udzielenie Radzie Ministrów wotum nieufności. Z uwagi na fakt, że - poza omawianym zakazem wycofywania podpisów zawartym w art. 115 ust. 2 regulaminu Sejmu - nie sposób wskazać takiego przepisu regulaminowego, który mógłby rzutować na analizowany problem, należy uznać, że jest on rozstrzygalny na podstawie właśnie przywołanego przepisu. Wycofanie wniosku trzeba by uznać za wycofanie wszystkich podpisów poparcia tego wniosku, a tym samym czynność niedopuszczalną w świetle art. 115 ust. 2 regulaminu Sejmu. Należałoby w konsekwencji wykluczyć kategorialną odmienność pojęć „wycofania podpisów” w rozumieniu tego przepisu od „wycofania wniosku” (opartego na nieznanej podstawie prawnej). Warto zauważyć, że konstytucyjna kompetencja w zakresie złożenia wniosku o udzielenie Radzie Ministrów wotum nieufności przysługuje grupie posłów, bez dodatkowego określenia cechy łączącej członków tej grupy. W sytuacji, gdyby cecha taka była normatywnie przewidziana, np. jako obowiązek przynależności członków owej grupy do tego samego klubu, wydaje się, że można byłoby oba wskazane wyżej pojęcia rozdzielać, wskazując przykładowo, iż prawo wycofania wniosku przysługuje, w imieniu całej grupy, przewodniczącemu danego klubu. W obecnym stanie prawnym brak jest jednak podstaw dla tego typu rozumowania.

Na marginesie warto dodać, że niezasadne byłoby ewentualne przyznawanie prawa wycofania wniosku o udzielenie Radzie Ministrów wotum nieufności wyłonionemu spośród sygnatariuszy wniosku przedstawicielowi. Należy bowiem

7 L. Garlicki, Rada Ministrów: powoływanie - kontrola - odpowiedzialność [w:] Rada Ministrów. Organizacja i funkcjonowanie, red. A. Bałaban, Kraków 2002, s. 164.

8 S. Patyra, Konstruktywne wotum nieufności jako formuła tworzenia i dymisji Rady Ministrów, „Przegląd Sejmowy” 2001, nr 1, s. 15.

$9 \quad$ A. Szmyt, $W$ sprawie aspektów prawnych wiążacych się $z$ powoływaniem $i$ odwoływaniem rządu, „Przegląd Sejmowy” 2007, nr 5, s. 161.

$10 \quad$ K. Wojtyczek, Uwagi do art. 115 regulaminu Sejmu, op. cit., s. 518.

11 A. Szmyt, W sprawie aspektów prawnych, op. cit., s. 161, 162. 
zauważyć, że regulamin nie przewiduje expressis verbis funkcji przedstawiciela wnioskodawców w analizowanym postępowaniu. Stąd w piśmiennictwie przyjmuje się, że rozpatrzenie wniosku przez Sejm jest dopuszczalne, nawet gdy wybrany przez grupę posłów (w istocie nieformalnie) przedstawiciel wnioskodawców zrezygnował z tej funkcji ${ }^{12}$.

\section{Podsumowanie}

Nie jest dopuszczalne wycofanie wniosku o udzielenie Radzie Ministrów wotum nieufności.

\section{Bibliografia}

Garlicki L., Rada Ministrów: powoływanie - kontrola - odpowiedzialność [w:] Rada Ministrów. Organizacja i funkcjonowanie, red. A. Bałaban, Kraków 2002.

Mordwiłko J., Czy rezygnacja reprezentanta wnioskodawców, przedkładajacych wniosek o votum nieufności wobec ministra, wywołuje skutki prawne $w$ sferze możliwości rozpatrzenia wniosku przez Sejm? [w:] Regulamin Sejmu w opiniach Biura Analiz Sejmowych, t. I, red. W. Odrowąż-Sypniewski, Warszawa 2010.

Odrowąż-Sypniewski W., Rola przedstawiciela wnioskodawców w procedurze rozpatrywania przez Sejm wniosku o wotum nieufności dla ministra [w:] Regulamin Sejmu w opiniach Biura Analiz Sejmowych, red. W. Odrowąż-Sypniewski, t. I, Warszawa 2010.

Patyra S., Konstruktywne wotum nieufności jako formuła tworzenia i dymisji Rady Ministrów, „Przegląd Sejmowy” 2001, nr 1.

Sokolewicz W., Uwagi do art. 158 [w:] Konstytucja Rzeczypospolitej Polskiej. Komentarz, t. I, red. L. Garlicki, Warszawa 1999.

Mojak R., Parlament a rząd w ustroju Trzeciej Rzeczypospolitej Polskiej, Lublin 2007.

Szmyt A., W sprawie aspektów prawnych wiążacych się z powoływaniem i odwoływaniem rzadu, „Przegląd Sejmowy” 2007, nr 5.

Wojtyczek K., Uwagi do art. 115 regulaminu Sejmu [w:] Komentarz do regulaminu Sejmu, red. A. Szmyt, Warszawa 2018.

12 J. Mordwiłko, Czy rezygnacja reprezentanta wnioskodawców, przedkładających wniosek o votum nieufności wobec ministra, wywołuje skutki prawne w sferze możliwości rozpatrzenia wniosku przez Sejm? [w:] Regulamin Sejmu w opiniach Biura Analiz Sejmowych, t. I, red. W. Odrowąż-Sypniewski, Warszawa 2010, s. 546. Zob. też W. Odrowąż-Sypniewski, Rola przedstawiciela wnioskodawców, op. cit., s. 547, oraz K. Wojtyczek, Uwagi do art. 115 regulaminu Sejmu, op. cit., s. 519. 